\title{
'Anti-Benthamism': Utilitarianism and the French Liberal Tradition
}

\section{Citation}

Welch, Cheryl B. 2012. 'Anti-Benthamism': Utilitarianism and the French Liberal Tradition. In French Liberalism from Montesquieu to the Present Day, ed. Raf Geenens and Helena Rosenblatt, 134-151. Cambridge: Cambridge University Press.

\section{Published Version}

doi:10.1017/CB09781139084178.011

\section{Permanent link}

http://nrs.harvard.edu/urn-3:HUL.InstRepos:11986332

\section{Terms of Use}

This article was downloaded from Harvard University's DASH repository, and is made available under the terms and conditions applicable to Other Posted Material, as set forth at http:// nrs.harvard.edu/urn-3:HUL.InstRepos:dash.current.terms-of-use\#LAA

\section{Share Your Story}

The Harvard community has made this article openly available.

Please share how this access benefits you. Submit a story.

Accessibility 


\section{Utilitarianism and the French Liberal Tradition}

Cheryl B. Welch

In her introduction to the 1984 edition of Tocqueville's texts on prisons, Michelle Perrot calls Tocqueville the "anti-Bentham."1 I note this judgment at the beginning of an essay on utilitarianism and the French liberal tradition less to dispute an interpretation of Tocqueville than to call attention to the phrase itself. When Perrot exonerates Tocqueville from an association with Bentham, she can count on bringing alive in the minds of her readers an immediate sense of what Tocqueville was not: a one-sided thinker who reduced the complexities of social life to self-interest, a dogmatic utopian, a protototalitarian with a mania for control and surveillance, in other words, a "utilitarian."

Unlike its place in Anglo-American intellectual life, where it functions as inspiration or worthy antagonist, utilitarianism in France is either largely invisible or used as a denigrating short-hand for what is wrong with modernity. As the philosopher JeanPierre Dupuy put it in 1995: “we know nothing about it because we don't want to know anything." 2 The purpose of this essay is to examine how this particular state of intellectual affairs came to be. Why, given common roots in the eighteenth century, did utilitarianism disappear as a serious system of thought in nineteenth-century France? After addressing this question, I turn to a few significant exceptions: moments of complex appreciation by French thinkers who deliberately engaged in a dialogue with utilitarianism. This part of the essay is less about the doctrine of utility than about its ability to provoke a particular kind of reflection in France. I suggest that these 
exceptional voices - my examples are Tocqueville and Elie Halévy—use a discussion of the fate of utilitarianism in another social and political milieu as a kind of disruptive detour, a way to jolt their readers into a new perspective on the possibilities of political life. In doing so, they illustrate a distinctive impulse in French liberalism.

Let me turn, then, to the question of why the discourse of utility is largely absent from French intellectual life. Lest you think this claim an exaggeration, consider the following examples. First, no French history of modern liberalism gives a prominent or sympathetic place to utilitarianism. If it is mentioned at all, it is as a synonym for "merely" economic liberalism and thus as a foil for some alternative conception. ${ }^{3}$ The French fate of Elie Halévy's work on philosophical radicalism provides a second example. In 1995, The Presses Universitaires de France decided to publish a new edition of Halevy's classic, The Growth of Philosophical Radicalism. At least part of the reason appears to have been to encourage consideration of Anglo-American political thought, particularly that of John Rawls. By the 1990s the work of Rawls was well known in France, but its appreciation and appropriation was impeded by the inability of French audiences to understand Rawls's protracted engagement with utilitarianism. Why would he have picked such an interlocutor? Belatedly discovered was the surprising fact that a well-known French scholar and public intellectual, author of l’Ére des tyrannies, had written a long and serious book on liberalism and the doctrine of utility. Moreover, this text was a classic in England and America but was largely unknown to French readers, available only in a crumbling American paperback edition. Unfortunately, Halevy's discussion of utilitarianism shed little light on contemporary Anglo-American philosophy — hence the rather awkward editorial decision to forego a scholarly critical 
edition for one that appended to each volume a "postface" by a contemporary philosopher or economist.

It may seem that the very distinguished group of French Bentham scholars associated with the Centre Bentham and with a new translation of Bentham's works put the lie to my assertion that anti-Benthamism is still the default pattern in French intellectual life. But I think they make my case, for these scholars take ignorance and dismissal of utilitarianism as the starting point for their project. In June 2009 when the Centre Bentham and the University of Rennes held a conference on "Two Centuries of Utilitarianism," the prospectus noted at the outset that "utilitarianism remains largely misunderstood in France, where it has been reduced to a couple of caricatured positions which disparage its image."

\section{Nineteenth-century marginalizations}

In accounting for the ever-increasing marginalization of the doctrine of utility in nineteenth-century France, I will simplify matters by putting to the side its most trenchant critics: Catholic conservatives and various circles of positivists and socialists. We might expect these groups to be hostile. ${ }^{4}$ Instead, I focus on those who wished to build a representative political regime in the wake of the Revolution. Whereas in England political liberals were either receptive to utilitarian ideas or gave them a serious hearing, in France, these ideas were met with indifference or outright antipathy in liberal circles. ${ }^{5}$ In order to sketch out the contours of this rejection, I offer the following relatively uncontroversial general descriptors of utilitarianism as a system of thought. First, it is consequentialist. Utilitarians posit that the rightness or wrongness of an action is due to the goodness or badness of its consequences. Second, it is rooted in the senses and in 
want satisfaction. Utilitarians characterize well-being in a way that has something to do with the priority of perceived needs and desires. Finally, it is concerned with aggregating goods and using that aggregation as a criterion of public policy. Thus utilitarians find a congenial home in economics. Ultimately, these three characteristics-consequentialism, sensationalism, and an affinity for economic theory—proved to be unsurpassable roadblocks to a serious consideration of utilitarianism in post-Revolutionary France.

Let me turn first to consequentialism, beginning with the key role of Etienne Dumont. More than any other text, Dumont's three volume work, compiled from Bentham's manuscripts and published in 1802, created the systematic doctrine known as "Benthamism." There are several scholars currently engaged in a close reading of Dumont's Bentham as against the "esoteric Bentham" of the original manuscripts, and detailed studies of his distortions (sometimes deliberate, sometimes inadvertent) of Bentham's texts have begun to emerge. ${ }^{7}$ What is clear is that Dumont produced only a partial version of the early Bentham, a portrait shaped by the concerns of the moderate liberal milieu in France during the Directory and Empire, a group among whom Dumont had many friends and connections. In the set of writers known as the Idéologues we find the same focus on the consequences rather than the inherent rightness of reforms, the same rejection of natural rights rhetoric as unstable and incendiary in favor of the more certain language of utility, the same grandiose hopes for utility as an overarching science that would end the chaos in morals, and the same emphasis on a particular psychology of the association of ideas. ${ }^{8}$ These close associations between Dumont's Bentham and the Idéologues served to link Bentham's fortunes to theirs. ${ }^{9}$ 
In the consequentialist language of utility, Dumont and the Idéologues hoped to find a neutral conciliatory principle that could bring together all parties of good will and consolidate and advance the civil gains of the Revolution. Ironically, however, this move from natural rights to utility antagonized rather than enticed possible allies and triggered an unease greater than any remorse over having naively trumpeted the rights of man. It reminded the French public both of the frenzy of utilitarian rhetoric that had precipitated the drastic reforms of the early years of the Revolution and of the many subsequent episodes in which arbitrary measures were rationalized as necessary to the good of all.

In A Rhetoric of Bourgeois Revolution, William Sewell reminds us of the pervasiveness of appeals to general utility in the 1780 s, a period in which reformers often conflated natural rights and utility, and in which "privileged bodies, even the nobility, defined and defended their interests in utilitarian terms instead of by citing their venerable privileges. ${ }^{, 10}$ We might also remember that Helvetius's book De l'Esprit, with its vague criterion of social utility, had an extraordinary resonance in the thirty years before the Revolution, and had in fact helped to disassociate the state from the person of the king. ${ }^{11}$ Sewell argues that the pervasiveness of the language of utility in Old Regime public discourse and in the early revolutionary period allowed participants in the Revolution to avoid facing real issues surrounding privilege. If the concepts of the philosophes became "banal" when used in the defense of any and every Old Regime interest and institution, nevertheless the widespread use of this utilitarian language also affected its speakers, who began to think in terms that would eventually corrode their own privileges, terms that "made the public feel that such institutions hardly existed any more, so that abolishing them would require only the suppression of a handful of flagrant 
abuses rather than the traumatic dismantling of an entire social order." 12 Many conservative liberals who had supported the early reforms of the Revolution began to view consequentialist arguments as naïve self-deception, a kind of amnesia about the realities of social order, symbolized in the frenzied renunciations of August 4. Under the romantic rhetoric of the public good, they now feared, lurked a revolutionary threat that would spring out to blindside participants.

At the same time, appeals to social utility had also become suspect among chastened republicans who remembered only too well how calls to rally around the social good seemed to have changed in a flash from a code for criticizing royal government to a code for supporting the Committee of Public Safety. Finally, Napoleon's cynical uses of consequentialism turned the language of utility into the language of collaboration. In a speech to the Council of State, for example, he justified deporting his Jacobin critics for an assassination attempt generally known to have been committed by royalists because any criticism of the first consul was not in the public interest. "It is permissible to examine the question whether, apart from any direct complicity with the authors of the attempt of the 2 Nivôse, the public interest does not require these people to be deported."13 Social utility, c'est moi.

In light of the use of utilitarian rhetoric both to justify revolutionary terror and to excuse absolutist repression, what seemed most urgent to moderates, and what would capture many in the post-revolutionary generation, was a rehabilitation of spiritualism and rights talk. I take my initial bearing from Madame de Staël and Benjamin Constant, who moved progressively away from their erstwhile allies the Idéologues and signaled this distancing by an attack on Dumont's translation of Bentham. ${ }^{14}$ I want to emphasize 
two themes common to their repudiation of the so-called defective philosophy of utility: its alleged inability to account for the Revolution's depravity and its inherent instability. Madame de Staël argues that to describe moral and political reasoning in the language of reflection on interest, of calculability, means that we can speak only of mistakes, not of crimes. ${ }^{15}$ In her view, however, the disastrous decisions taken by revolutionary agents were much more than errors in calculation. They called for a different quality of scorn or disapprobation. We recognize mistakes by their bad consequences, she argued, but we mark crimes by a more intimate sense of violation of the self and its duties. Meditating on the nature of one's own moral revulsion reveals that there is a different source for moral judgment than calculation of consequences: a self that participates in some transcendent order of value. I will return below to this preoccupation with the perceived need for an autonomous and stable self.

A second theme common to Staël and Constant is the expression of deep distrust and uneasiness over the instability and malleability of the notion of the happiness of the greatest number as a justification for public actions. After Staël's chapter in De l'Allemagne criticizing "morality founded on personal interest" we find a chapter criticizing morality "founded on the national interest." The clear referent is Napoleon's rhetoric of governing in the interest of all by manipulating individual interest and ambition, and by repressing personal liberty and judgment for the sake of social peace. What was needed, according to Madame de Staël, was not a way to excuse cowardly knuckling-under to a despot but rather a way to induce heroic refusals. In a similar vein, Constant worried that utilitarianism as explicated by Bentham would cut the ground from 
under the judicial subject who wished to oppose laws of the sovereign that had crossed a moral line.

Because he was so attuned to the likely effects of rhetorical strategies, Constant had a particularly subtle explanation of the drawbacks of the language of utility in the post-Revolutionary context, a situation in which the establishment of stable representative democracy required citizens and leaders to internalize the idea that popular sovereignty had moral limits. ${ }^{16} \mathrm{He}$ is also a good guide because in many ways his differences with Bentham and the Idéologues were not profound, and he continued to see them as political allies. Constant admired Bentham, for example, precisely because he thought Bentham had not justified a "holocaust of individual citizens" by personifying citizens en masse. ${ }^{17}$ In his critique of political fallacies, Bentham refused to sacrifice the happiness of concrete individuals to abstract holistic fictions. Nevertheless, in a practical choice between rights and utility, Constant believed that the responsible theorist must abandon Bentham and take a stand with the Declaration of the Rights of Man. Constant proceeded to turn the utilitarian critique of natural rights on its head. While he thought it was true that proclaiming the natural rights of the citizen opened the way to uncertainty and differences of opinion, appealing to utility was yet less sure and more contentious and arbitrary. On the one hand, it would lead to an increase in insecurity among common citizens. To tell someone he had a right would induce a greater sense of security than to say that it was useful that such a person not be punished. ${ }^{18}$ Moreover, utility could not provide a stable foundation for law. To appeal to utility was to encourage in lawmakers the habit of weighing advantages and losses. But the calculation of such consequences 
was psychologically associated with arbitrary and reckless judgments, with chaotic change in law rather than legal continuity.

As a rhetorical choice for liberals, then, appealing to the consequentialist criterion of utility appeared very dicey. To insist that private or public actions were justified by their consequences brought to mind self-deception, social and political instability, the justification of terror, craven collaboration, and cynical raison d'état. This was company to be avoided.

Let me turn to my second descriptor of utilitarianism: its relationship to sensations, to pleasures and pains. In the context of the early nineteenth century, both the followers of Bentham and of the French Idéologues yoked their use of utility as a criterion in moral and public life to a theory of associationist psychology known as sensationalism, that is, to the legacy of Locke by way of Hartley and Condillac. Briefly the official philosophy of France during the Directory, and the basis of a curriculum in primary and secondary schools, sensationalism in some version was pervasive throughout the revolutionary and Napoleonic periods.

One way to think about the attractiveness of this psychology during the revolutionary period is to remember that the corporate structure of the Old Regime was a necessary underpinning of persons as well as of social hierarchy. The sudden dismantling of an order in which moral norms were imposed by corporate bodies produced anxieties about mental functioning as well as social order. During the Revolution the Idéologues proposed as a substitute for this traditional order their notion of a social science based on association of ideas, of science as a well-made language. Though they themselves rejected Jacobinism, nevertheless many observers saw festivals and other deliberate 
interventions in the social environment as a kind of applied sensationalism, as an attempt to create new bonds between citizens by inducing more rational trains of ideas that would function as replacements for superstition and the dead weight of custom. ${ }^{19}$

Yet most schemes of revolutionary education and experimentation were either stillborn or obvious failures. These failures released — to use an anachronistic Freudian term - much free-floating anxiety in liberal circles about how both elites and the masses would acquire enough rational ballast to create and sustain democratic institutions. Hence the new attractiveness of both Protestantism and Jansenism in these circles, faiths that appeared to bolster liberal judgment and produce constancy of character without relying on outside authority. But Protestantism was not a viable religion for most of the French, and Jansenism was less a living faith than an inspiring myth. ${ }^{20}$ Most of the new generation turned not to religion, but to philosophy. Perhaps the most important figure to indicate a philosophical way out of their predicament—-that is, the failure of sensationalist psychology to ground a new moral consensus - was the wayward Idéologue, Maine de Biran, who indirectly provided the philosophical substructure of nineteenth-century French liberalism. ${ }^{21}$

Biran began as a rather orthodox sensationalist and disciple of Destutt de Tracy. During the Napoleonic period and the Restoration, however, he began to deviate from Idéologue orthodoxy by exploring the autonomous aspects of consciousness. He had long kept a journal, an astute self-examination in which he bemoaned the fact that he and his co-revolutionaries seemed to be the playthings of their surroundings- "Tout influe sur nous, et nous changeons sans cesse avec ce qui nous environne." ${ }^{, 22}$ In contrast, he looked for a fixed and independent center that would be accessible through introspection and 
would be able to master its own impressions and ideas. Biran himself made the link between the flimsy fragmented faculties allegedly attributed to the self in sensationalist psychology and a failure to provide the robust moral notions necessary for a healthy political community. Moreover he invokes older French Catholic sources that had long criticized Locke and Lockeanism as inconsistent with a Catholic Christian notion of a responsible self. ${ }^{23}$ While the spiritualism of Mme de Staël and Constant had affinities with purified and individualistic forms of Protestantism — and thus remained suspect in the French context-Maine de Biran offered a better bridge to Catholic sensibilities, even ones that were no longer overtly religious.

At his death, Maine de Biran's unpublished manuscripts apparently weighed sixty pounds and these weighty papers had been widely circulated. Most important, he was picked up by Victor Cousin, who built an enormously successful educational and institutional project on a critique of Locke and what he called the "sensualist" school. Cousin's attack on the existing sensationalist basis of utilitarianism, linking it to moral confusion and anarchy and arguing that it could never lead to a stable social order, centered on its alleged faulty conception of the self-weak, wavering, and susceptible to reckless idealism or sordid materialism. Cousin's alternative method of "interior observation" was not without sharp critics. Stendhal noted that looking within was no guarantee of finding anything, and he sarcastically concluded that Cousin's pedagogical philosophy rested on the vacuous command to "fermer les yeux et de chercher dans leurs consciences. ${ }^{24}$ Cousin was nevertheless a mesmerizing speaker and something of an entrepreneurial and organizational genius. As a member of the Council of Public Instruction, he was able to embed his alternate psychology and philosophy in the 
educational structure of nineteenth-century France. His so-called eclecticism thus became the foremost shaper of several generations of state-educated elites, who cut their teeth on a refutation of sensationalism and utilitarianism.

I now turn to my final point about the fate of the philosophy of utility among postrevolutionary moderates: its relationship to economics. This is not the place to rehearse the distinctive path of economics as a discipline in France, but we might begin by remembering the reception of certain giants of early twentieth century economic thought -for example, Walras - in their native France. All met with wide-spread resistance in a profession ensconced in faculties of law, and all initially found their models rejected as abstractions that threatened to diminish human dignity. Charles Rist wrote to Walras in 1906 that economics in France was "specific, descriptive, and literary, marked by a deep and general indifference toward any kind of theory or theoretical research.. ${ }^{25}$ Many have noted the long refusal of French liberalism to accept the economy as a social reality capable of being illuminated by a disciplined body of thought. ${ }^{26}$

Political economy emerged only very slowly as a distinct field of study in nineteenth-century France. The most eager proponents of both political economy and classical laissez-faire in the early part of the century were followers of Tracy, Say, and Bentham, known as the "industrial school." Always a minority voice, many of themfollowing J.B.Say himself-also resisted the narrowing of the discipline and expressed a desire for a more capacious social analysis that would draw out the connections with law, morals, and history. Several key figures drifted into the orbit of the Saint Simonians. The single most influential conduit for the ideas of classic political economy in the 1820 s was the liberal journal of opinion The Globe, which published long articles on Say, Malthus 
and Ricardo. ${ }^{27}$ But the Globe was edited by followers of Cousin, whose stated aim was to purge economics of "the utilitarianism of Bentham or the idéologie of Condillac."28 They defended a rather extreme form of laissez-faire/laissez passez that was also particularly hostile to social welfare measures on the grounds of the need to recognize the moral duty of each member of society to be responsible for his own autonomous self. Those thinkers who did self-consciously take on the task of theorizing the social question- - the St. Simonians, the Catholic school of "social economists" or mavericks like Sismondi—were also overtly and vocally anti-utilitarian and explicitly critical of the Idéologues and Bentham. They identified the philosophy of utility with a defective science of political economy that made a mockery of the phrase "the greatest good of the greatest number." 29 Already suspect because of its consequentialism, materialism, and association with economics, utilitarianism in its Bentham/Dumont form had a final fatal flaw: it was perceived as indigestibly English. A favored polarity in the Protestant Swiss Dumont's presentation of Bentham was that of Bentham's English depth and seriousness versus the superficiality and outward show of French theorists. ${ }^{30}$ Whether enmeshed in the anglophilia of the (very) few or the Anglophobia of the majority, discussions of utilitarianism often dwelled on its English pedigree, rather than its universal applicability, and this association with perfidious Albion could be interpreted as an affront to national honor. Until recently Bentham's own claims to originality and the focus of Bentham scholars on his rationalistic and systematizing biases have often combined to make him seem sui generis in England - the most continental and atypical of English theorists. Only recently have his projects of law reform been rooted in English soil. ${ }^{31}$ Ironically, however, French receptions often associated Bentham with an English alternative that 
either was alleged to reflect a distinctive national character or to have evolved out of special conditions. For those very reasons, he was often dismissed as an unreliable guide.

So far I have pointed to coalescing points of attack on utilitarianism among liberals in France: its consequentialist rhetoric and sensationalist foundations were criticized as dangerous, destabilizing, and immoral, and its connections to economic liberalism were dismissed as limiting or unnecessary, if not—as some went so far as to say-sordid and anti-French. I now want to make one large claim. Considering that utilitarianism was under simultaneous attack by conservatives as Godless and by socialists and positivists as unscientific, these multiple repudiations from the center established a pattern of indifference and hostility that was largely set by mid-century. Henceforth, utilitarianism appears largely as an oppositional construct: a simplistic foil for successive waves of academic consolidators in economics, sociology, and law. In the twentieth century, when Foucault takes Bentham's Panopticon as a potent symbol of the coercive disciplinary side of allegedly enlightened reform schemes, the cultural soil had already been well-prepared to receive Bentham as a bad seed. Bentham the sinister precursor of totalitarianism joined Bentham the proponent of soulless economic calculation. To be a utilitarian was to go over to the dark side of modernity.

\section{Pattern Breaks}

I turn now to a brief discussion of two dissident French voices who resist this disdain for utilitarianism. Although they write sixty years apart, in very different circumstances, and from quite different intellectual formations -and although neither was a utilitarian — both Alexis de Tocqueville and Elie Halévy had empathetic encounters with aspects of utilitarianism that were extraordinarily fruitful. I can do no more than 
sketch in broad strokes some commonalities in these moments of appreciation, which join a long philosophical tradition of French observers of English liberty, but I want to note in particular the shared impulse to take what had become a negative caricature and turn it into a liberating trope.

Their first common move is to make a virtue of the vice of Anglo-Americanism or Englishness: to draw the foreign into the territory of subtle comparison rather than scornful contrast. In Tocqueville's Democracy in America and Old Regime, in Halévy's The Growth of Philosophical Radicalism and English histories, the American and English experiences become deliberate laboratories for studying modern political culture and for identifying the possible interactions among ideas, institutions, and political action. Tocqueville famously said that he saw in America "more than America" and Halevy's encounter with England was a vehicle for a lifelong meditation on the values of individualism, liberty, and the legacy of the Enlightenment in Europe. ${ }^{32}$ This close examination of another society to illuminate more general lessons involves a deliberate rejection of the salience of national character to theoretical analysis. In a letter to a friend, Halévy noted acerbically "Bentham is no doubt a purely English phenomenon, just as Marx is a purely German, or even a purely Jewish phenomenon. But what is the use of reasoning like this?"33 In fact, Tocqueville and Halévy perceived in America and England a fertile mix of familiarity and distance: close enough to be brought in the same comparative frame, far enough away to induce analytical clarity. Indeed they use the same language to describe their first encounters with American or English patterns of behavior and institutions; these patterns "astonish;" they jolt the observer into a kind of wondering curiosity which is the basis of all critical reflection. ${ }^{34}$ 
What do these writers see when they peer into this Anglo-American parallel universe? Not a world of abstract utilitarian maximizers, but rather groups of people who speak the language of utility in a dialect quite unfamiliar to the French. In this world, familiar ideas have unanticipated consequences, and entities thought to be mutually exclusive live together in practice : consequentialist rhetoric coexists with political stability and continuity; those who proclaim themselves to be motivated by pleasure and pain practice asceticism; dogma does not always drive out tolerance; the clash of doctrines leads to political compromise; and zeal does not lead to the barricades. Let me describe briefly how different pictures of this world come into focus first in Tocqueville, then in Halévy.

During his second trip to England, while he was writing Democracy in America, Tocqueville was struck by the strange sight of a philosophical radicalism that - so he thought—-posed no revolutionary threat. As in America, he was surprised by the ways in which Radical behavior confounded his expectations. Like their French counterparts, they appeared to be dogmatists on issues like popular sovereignty, universal suffrage, and the superior moral claims of the many over the few. Yet they combined zeal with acceptance of compromise, co-existing in a contentious reformist political space with the New Whigs. ${ }^{35}$ Tremendously excited by the "confusion of contrary tendencies in English development" ${ }^{36}$ Tocqueville tries to theorize and synthesize these tendencies in his famous chapters on the Anglo-Americans' embrace of self-interest properly understood in the second volume of Democracy in America. ${ }^{37}$ "The doctrine of self-interest properly understood is not new," Tocqueville writes, "but it has been universally accepted by today's Americans. It has become popular. It lies at the root of all action. It crops up in everything Americans say." ${ }^{38}$ Tocqueville's fundamental innovation in these key 
chapters, and throughout the text of Democracy in America, was to view the practical fusion of private interest and public utility that he claimed to have found in the United States as a dense sociological and psychological artifact, and to explore the conditions under which, and the mechanisms by which individuals come to desire what is in their long-term interest. He praised this new kind of applied utilitarianism that bridged economic, political, and religious spheres, especially through the mechanism of association.

Tocqueville here contests Benjamin Constant on his own grounds and does him one better. Consequentialist rhetoric has no intrinsic psychological associations; it is entirely capable of being combined with notions of sacrifice, stable deferred gratification, religious attitudes, and even a kind of honor depending on how it is embedded in institutions and moeurs. Indeed, his point is that the American example shows us that democratic utilitarianism is completely compatible in practice with a form of freedom. But we cannot grasp these complex enabling patterns of behavior by considering ideas in abstraction. What we need is a description of how ideas function in certain selfreinforcing social, economic, political and religious spheres and how those ideas in turn shape social life. Not a history of ideas, but a thick elucidation of ideas in history.

Like Tocqueville, Elie Halévy begins his studies of England with a sense of its ability to arouse what he calls a "valuable capacity for wonder." ${ }^{\text {"39 }}$ The Philosophical Radicals in particular challenge many of his own assumptions about the utilitarian "type". Halevy notes — as did Tocqueville — that consequentialist rhetoric could express a high moralism and that utilitarian pleasure looked a lot like bourgeois discipline, pain avoidance, or abstinence. How did Halevy capture and describe this set of opposites? 
Henri Bergson wrote to Halévy in 1904 that he admired Halévy's method of discovering different tendencies from those that one would normally expect by drawing out the latent postulates of systems of ideas. ${ }^{40}$ I want to examine this practice by looking at the most famous example of it: Halevy's analytic distinction between the artificial identification of interests_and the natural or spontaneous identification of interests, a latent contradiction that he places at the heart of his narrative of utilitarian theory and practice over half a century.

Many commentators—especially among contemporary French neo-liberals—see Halevy as particularly prescient for noticing the despotic tendencies inherent in the artificial identification of interests, for drawing out the analogy between utilitarianism and its Rousseauistic cousin, a democratic theory that tended to distrust all intermediary powers and social divisions and led to an absolutist democracy. ${ }^{41}$ But I would argue that Halévy's use of the analytic distinction between artificially and naturally identified interests has a different center of gravity. In fact Halévy uses it in a more even-handed way to map out how these contradictory principles were combined in various practices and continually adapted to different realities. A close reading also reveals that the lure of the idea that interests would be spontaneously identified, as in markets, was for him as dangerous an illusion as that they must be artificially combined by the legislator. $\mathrm{He}$ admired the historical trajectory of philosophical radicalism in part because he found within it the lesson that these two thought experiments - one leading to an omnicompetent rational state and the other leading to a society of sovereign individuals, what he called rationalism and individualism — could be held by the same people and peacefully combined in changing concrete situations. Rather than blaming utilitarians for 
not seeing the incoherence in their own practice or the dangerousness of their principles, he praises them for living with inconsistency. Some such balance, some such restraint from the drive to realize the full implications of ideas in practice was necessary for a modern nation to become free, that is to become "a country of voluntary obedience, of an organization freely initiated and freely accepted." ${ }^{\prime 42}$

Halévy's recognition of a link between the doctrine of utility and behavior patterns of self-restraint and self-discipline leads him ever more deeply into what might be called the "social world" of the English people; he is interested particularly in aspects of the social ethos that blunt the emergence of violent power struggles, but do not completely inhibit reform. His magisterial six-volume work on the History of the English People displays a command over a remarkable range of subjects — administrative institutions, the legal profession, local government, the press, parties, land tenure, forms of religious and artistic experience — and illustrates his move from sociologicallyinformed intellectual history to what he calls straight history. But his is a straight history that takes ideas seriously. It is here that he develops his still- influential thesis about the prophylactic effect of Methodism, i.e., the tendency of evangelical religion to counteract revolutionary tendencies in England. As Tocqueville did for America, Halevy explores the tangled mix of religious and utilitarian ideas in both motivating and restraining individual initiative. "The fundamental paradox of English society," he concludes ". . is precisely the partial junction and combination of these two forces theoretically so hostile." It is a mixture, he says, "whose constituents are often mingled beyond the possibility of analysis, a compound of Evangelicalism and Utilititarianism." 


\section{Conclusion}

Both Tocqueville and Halévy, then, narrate counter-histories to that of the French: histories in which utilitarian ideas did not whither, but were embedded in a complex set of practices that in some way tempered the disruptive effects of rationalism and individualism without entirely stopping them. I want to conclude with two thoughts on what can be learned from these reflective detours.

First, Tocqueville and Halévy themselves were clear on the lesson they wished to draw. These alternate paths did not represent a more desirable road-not-taken that the French should try to pursue. The utilitarian route was neither available nor desirable for the French. Rather, the lesson was that if rationalism and individualism could be tamed and harnessed in societies saturated with utilitarianism, these tendencies could also be controlled and guided in societies where they were expressed in another vernacular (like France). Moreover, these counter narratives offered clues to the ways in which the French might plot an escape route. By unsettling French views of reality, by showing the contingency of what looked like necessary oppositions, such detailed portraits could inform the art of public affairs by alerting both elites and citizens to potentially analogous moderating factors. They also showed the need for certain exemplary liberal virtues above all tolerance, compromise, and what Halevy called hopeful stoicism. He once said that studying the evolution of one's own convictions was like studying the history of a society; if we realized the accidental foundations of our settled convictions, we might give others a more patient hearing and be less likely to commit violence for an idea.

Second, these counter histories invite us to think about a kind of "presentist" history that is particularly characteristic of the French liberal tradition. Both Tocqueville 
and Halevy took it as axiomatic that the study of past theories and of the interaction of theories with political projects could not and should not be freed from the pressure of contemporary questions. Tocqueville's scholarly work was directly aimed at his contemporaries in the French political class and informed his own long political career, and Halevy wrote very early in his academic career that he wanted to be both reflective and active, to be a rationalist with "rage." 44

It is sometimes assumed that explicitly normative projects and truly historical works are like oil and water. History adds mere window dressing to analytic theory, while contemporary concerns lead to a flatfooted history that looks for ancestors, projects false connections between ideas into the past, and is tone deaf to the speech of the dead. This is sometimes the case. But not always. Philosophically motivated histories like those of Tocqueville and Halévy unsettle this conviction. Like their own counter-histories of a society in which apparently contradictory principles are conjoined and combined, their works suggest that passionate commitment to an interpretive hypothesis with obvious contemporary relevance can co-exist in creative equilibrium with erudition, skill, judgment, command of sources and a self-conscious desire not to distort. And the result can be work so illuminating and perceptive that it not only allows us to contest the interpretive historical hypothesis out of the richness of the work itself, but enlarges the political imagination.

\footnotetext{
${ }^{1}$ Euvres complètes d'Alexis de Tocqueville, ed. J.-P. Mayer, André Jardin, and Françoise Mélonio (Paris, 1951--) 4:1, 37.
} 
${ }^{2}$ Jean-Pierre Dupuy, "Postface," La formation du radicalisme philosophique: Elie Halévy, 3 vols., ed. Monique Canto Sperber (Paris: Presses Universitaires de France, 1995), Vol. 1, 332.

${ }^{3}$ See, for example, Georges Burdeau, Le libéralisme (Paris: Editions du Seuil, 1979) and André Jardin, Histoire du libéralisme politique (Paris: Hachette, 1985). Pierre Manent remarks that if the French were slow to enter the modern world in the nineteenth century, this failure at least saved them from falling into the abyss of utilitarianism, "La Révolution française et le libéralisme français et anglais," L'Heritage de la Révolution française, ed. François Furet (Paris: Hachette, 1989), 81. See also Pierre Manent, Histoire intellectuelle du libéralisme : dix leçons (Paris : Calmann-lévy, 1987) and Les Libéraux, 2 vols. (Paris : Hachette, 1986).

${ }^{4}$ A fuller treatment of my topic would need to address the pervasive nature of this hostility-including the particular nature of the Catholic moral and cultural revival, the polarized nineteenth-century French discourse around class and property, and the growth of a distinctive Saint-Simonian-inspired view of the public interest. I thank Stanley Hoffmann for raising these points in conversation and for his helpful comments on an earlier version of this essay.

${ }^{5}$ Although there were many criticisms and caricatures of the utilitarians in England in the nineteenth century, these did not seep into the very fabric of intellectual life, nor prevent the serious study or appreciation of utilitarianism. See J.R. Dinwiddy, "Early Nineteenth-Century Reactions to Benthamism" Transactions of the Royal Historical Society 34 (1984), 69.

${ }^{6}$ Traités de législation civile et pénale, précédés de Principes généraux de législation, et d'une Vue d'un corps complet de Droit: terminés par un Essai sur l'influence des Temps et des Lieux relativement aux Lois. Par. M. Jérémie Bentham, jurisconsulte anglois, publiés en français par Et. Dumont, de Genève, d'après les Manuscrits confiés par l'Auteur, 3 vols (Paris: Bossange, Masson et Besson, 1802). On the influence of this work, see Cyprian Blamires, The French Revolution and the Creation of Benthamism (New York: Palgrave Macmillan, 2008), 254: "[Dumont] established Benthamism as a creed in the public mind and created its shape and form for posterity." See also David Lieberman, "From Bentham to Benthamism," The Historical Journal 28:1 (March 1985), 210.

${ }^{7}$ See the essays in Bentham et la France, ed. Emmanuelle de Champs et Jean-Pierre Cléro (Oxford: Voltaire Foundation, 2009), Part II "Bentham et Dumont: les premières traductions françaises", especially “'You have set me a strutting, my dear Dumont': la dette de Bentham à l'égard de Dumont," by Frederick Rosen. I thank Emmanuelle de Champs for allowing me access to this book in manuscript form.

${ }^{8}$ For further discussion of these themes, see my Liberty and Utility: The French Idéologues and the Transformation of Liberalism (New York: Columbia University Press, 1984).

${ }^{9}$ The affinity between Dumont and the Idéologues is particularly clear in the Preface to the 1802 Traités, which argues that the form of government is not important, that the heirs of the revolution should turn to the rhetoric of utility as a force for stability and conciliation, and in particular that they should substitute this more scientific language for the deceptive tropes of natural rights.

${ }^{10}$ William Sewell, A Rhetoric of Bourgeois Revolution: the Abbé Sieyès and What is the Third Estate? (Durham: Duke University Press, 1994), 142.

${ }^{11}$ See Pierre Rosanvallon "L'utilitarisme français et les ambiguités de la culture politique prérévolutionnaire (position d'un problème)" The Political Culture of the Old Regime, ed. Keith Michael Baker (Oxford: Pergamon Press, 1987), 436-438 and Lucien Jaume, Tocqueville : les sources aristocratiques de la liberté (Paris : Fayard, 2008), 201-202.

${ }^{12}$ Sewell, Rhetoric, 143. 
${ }^{13}$ The Mind of Napoleon: A Section from his Writings and Spoken Words, ed. and trans. J. Christopher Herold (New York: Columbia University Press, 1961), 91.

${ }^{14}$ Germaine de Staël's critique appeared in De l'Allemagne $(1810,1813$ - —one of the most important and widely read books in the post-revolutionary period. See De l'Allemagne, 5 vols. (Paris, Librairie Hachette, 1959), 4: 283-317. Constant's discussion of Bentham appears in several texts (sometimes reproduced verbatim) written from 1806 through the 1820s. For a discussion of these texts, see Marcel Gauchet, ed., Benjamin Constant, Écrits politiques (Paris: Gallimard, 1997), 509.

${ }^{15}$ Staël, De l'Allemagne, 4 :286. Lucien Jaume sees this critique as a premonition of the shrinking discursive universe of French liberalism: "she closes the door in France to a very important path that will be at the heart of English liberalism. . . that is, utilitarianism as the theory and practice of the harmonization of interest." L'Individu effacé ou le paradoxe du libéralisme français (Paris: Fayard, 1997), 40.

16 "Principes de politique, "Gauchet, ed., Constant : Écrits, 312-322.

${ }^{17}$ For a longer discussion of Constant's relationship to Bentham, See Jaume, L'Individu effacé, 91-103.

18 “Annexe 1 aux Principes de politiques,"Gauchet, ed., Constant : Écrits, 512 ; cf. “"De M. Dunoyer et de quelques-uns de ses ouvrages," Mélanges de littérature et de politique, ibid., 664-668.

${ }^{19}$ My discussion of this process is indebted to the illuminating analysis in Jan Goldstein, The PostRevolutionary Self: Politics and Psyche in France, 1750-1850 (Cambridge, MA; Harvard University Press, 2005), 21-138.

${ }^{20}$ I discuss the symbolic uses of Jansenism among liberals in "Jansenism and Liberalism: The Making of Citizens in Post-Revolutionary France, History of Political Thought 7 (Spring 1986), 151-65.

${ }^{21}$ Jaume, L'Individu effacé, 44.

${ }^{22}$ Maine de Biran, Journal, ed. Henri Gouhier, 3 vols. (Neuchatel: Éditions de La Baconnière, 1954-57), 3:3 (27 May 1794).

${ }^{23}$ Goldstein, Post-revolutionary Self, 136-137.

${ }^{24}$ Stendhal, New Monthly Magazine (September 1828), Courrier Anglais, ed. Henri Martineau, 5 vols. (Paris: Le Divan, 1935-36), 3:414.

${ }^{25}$ Quoted in Philippe Le Gall, "Economics," Columbia History of Twentieth-Century French Thought (New York: Columbia University Press, 2006), 188.

${ }^{26}$ Jean-Pierre Dupuy, "Postface,” Sperber, ed., Formation, Vol. 1, 333.

${ }^{27}$ See Jean-Jacques Goblot, La Jeune France libérale: Le Globe et son groupe littéraire 1824-1830 (Paris: Plon, 1995) 306-336 and Michael Drolet, Tocqueville, Democracy and Social Reform (London: Palgrave, 2003), 36-39.

${ }^{28}$ Goblot, La jeune France, 312.

${ }^{29}$ See Welch, Liberty and Utility, 171-187.

${ }^{30}$ Adopting a very different prose tone, Dumont completely omitted Bentham's sarcasm, wit, and vituperation in attacking English institutions,. See. J. R. Dinwiddy, "Bentham and the Early Nineteenth Century," Jeremy Bentham: Critical Assessments, ed. Bhikhu Parekh (London: Routledge, 1993), 238. 
31 For example, see L. J. Hume, Bentham and Bureaucracy (Cambridge: Cambridge University Press, 1981) and David Lieberman, The Province of Legislation Determined: Legal Theory in Eighteenth-century Britain (Cambridge: Cambridge University Press, 1989; 2002).

${ }^{32}$ Tocqueville noted, "While I had my eyes fixed on America, I thought about Europe." De la démocratie en Amérique, ed. Eduardo Nolla. 2 vols. (Paris: Librairie Philosophique J. Vrin, 1990) 1: 14, note n. And as François Furet astutely observed, Bentham's utilitarianism and its legacy in England constituted a sort of French Revolution à l'anglaise in the thought of Halévy. "Préface," Élie Halévy, Correspondence (18911937), ed. Henriette Guy-Loë (Paris: Editions de Fallois, 1996), 29.

${ }^{33}$ Halévy to Celestin Bouglé, 12 November 1896, Ibid, 185. On Tocqueville's rejection of national character as an explanatory variable, see James Schleifer, The Making of Tocqueville's Democracy in America (Indianapolis: Liberty Fund, 2000), 82-89, 95.

${ }^{34}$ See Elie Halévy, A History of the English People in the Nineteenth Century, 6 vols. trans. E. I. Watkin and D. A. Barker (London: Ernest Benn, 1960), Vol 1: England in 1815, Author's Preface, xii. Tocqueville continually reported on the "novel spectacles" he encountered in America. For example, see Democracy in America, trans. Arthur Goldhammer (New York: Library of America, 2004), Vol. I, Part 1, chap. $2,36$.

${ }^{35}$ Fascinated by a political culture that could tame opposite impulses, Tocqueville began to think that in England a history of involvement in parish meetings and in the court system had created fora where basic disagreements were mediated On this point see Seymour Drescher, Tocqueville and England (Cambridge, MA: Harvard University Press, 1964), 96.

${ }^{36}$ Ibid., 100.

37 "How Americans combat individualism with the doctrine of self-interest properly understood" and "How Americans apply the doctrine of self-interest properly understood in the matter of religion" DA, trans.

Goldhammer, Vol. II, Part 2, chaps 9 and 10, 610-616. Though Tocqueville doesn't mention utilitarianism by name, he clearly had in mind French utilitarian moralists. His original title for the chapter was "Of Interest Properly Understood as a Philosophic Doctrine," See DA (Nolla) 2:113.

${ }^{38}$ DA, trans Goldhammer, Vol. II, Part 2, chap. 8, 611.

${ }^{39}$ England in 1815, xii.

${ }^{40} 2$ January 1904, “Lettres de Leslie Stephen et de Henri Bergson (1901-1904)," Sperber, ed., Formation $3: 435$.

${ }^{41}$ Pierre Bouretz, "Postface,” ibid., Vol. 2, 314-316; Dupuy, "Postface,” ibid., Vol 1, 330.

${ }^{42}$ England in $1815,591$.

${ }^{43}$ Ibid., 585 and 587.

${ }^{44}$ Halévy to Xavier Léon, 31 August 1891, Correspondence, 65. 